ISSN 2080-1653

DOI 10.24917/20801653.322.3

\title{
MACIEJ SMĘTKOWSKI
}

Uniwersytet Warszawski, Centrum Europejskich Studiów Regionalnych i Lokalnych (EUROREG), Polska University of Warsaw, Centre for European Regional and Local Studies (EUROREG), Poland

\section{DoRota CELIŃSKA-JANOWICZ}

Uniwersytet Warszawski, Centrum Europejskich Studiów Regionalnych i Lokalnych (EUROREG), Polska

University of Warsaw, Centre for European Regional and Local Studies (EUROREG), Poland

\section{Wybrane przestrzenne aspekty restrukturyzacij przemystu w Europie Srodkowo-Wschodniej przed kryzysem gospodarczym 2008 roku}

\section{Selected Spatial Aspects of Industrial Restructuring in Central and Eastern European Countries in the Period before the 2008 Economic Crisis}

\begin{abstract}
Streszczenie: Artykuł ma na celu ocenę wybranych przestrzennych aspektów restrukturyzacji przemysłu w krajach Europy Środkowo-Wschodniej (EŚW) w okresie poprzedzającym kryzys gospodarczy w 2008 roku. Badania objęły zarówno porównawczą analizę procesów dezindustrializacji na poziomie krajowym, jak i zmiany znaczenia sektora przemysłowego w podregionach NUTS3 krajów EŚW. W szczególności zidentyfikowano te regiony, które z jednej strony odniosły sukces gospodarczy mierzony dynamiką wzrostu PKB w porównaniu do średniej krajowej, a z drugiej - odnotowały wzrost znaczenia przemysłu w strukturze wartości dodanej brutto. Trzy z nich objęte zostały pogłębionymi badaniami jakościowymi w ramach studiów przypadku, które miały na celu wskazanie czynników rozwoju, w tym roli instytucji i interwencji zewnętrznej w procesach restrukturyzacji gospodarczej. Badania pokazały, że skala sukcesu regionów, które przeszły udaną restrukturyzację przemysłu, była relatywnie niewielka. W procesach rozwoju tych regionów decydującą rolę odegrały czynniki egzogeniczne, w tym zwłaszcza napływ kapitału zagranicznego. Z kolei znaczenie czynników endogenicznych, takich jak wzrost innowacyjności przedsiębiorstw czy też rozwój małych i średnich firm, było w badanym okresie stosunkowo niewielkie. Istotna okazała się natomiast rozwinięta współpraca między głównymi interesariuszami rozwoju regionalnego i lokalnego, skutkująca właściwie sformułowanymi strategiami rozwoju układów terytorialnych objętych badaniami.
\end{abstract}

Abstract: The aim of the article is to assess selected spatial aspects of industrial restructuring in the Central and Eastern Europe (CEE) countries in the run-up to the 2008 economic crisis. The study includes both a comparative analysis of deindustrialisation processes at the national level as well as changes in the importance of the industrial sector in the NUTS3 regions of the CEE countries. In particular, the analysis enabled to identify regions that, on the one hand, achieved economic success measured by GDP growth in comparison to the national average, and on the other hand regions that noted an increase in the importance of industry in the gross value added structure. In three selected regions an in-depth qualitative research was conducted, aimed at identifying development factors, including the role of institutions and external intervention in the economic restructuring processes. The study shows that the scale of success of regions that underwent a successful restructuring of industry was relatively small. In the development processes of the regions exogenous factors played a decisive role, in particular the inflow of foreign capital. In turn, the importance of endogenous factors, such as the growth of innovativeness of enterprises or the development of small and medium-sized 
enterprises was relatively small. What was identified as a particularly important factor was cooperation between the main stakeholders of the regional and local development, resulting in properly formulated strategies of the territorial structures' development.

Słowa kluczowe: kraje Europy Środkowo-Wschodniej; restrukturyzacja przemysłu; rozwój regionalny Keywords: Central and Eastern European Countries; industrial restructuring; regional development

Otrzymano: 1 grudnia 2017

Received: 1 December 2017

Zaakceptowano: 15 maja 2018

Accepted: 15 May 2018

Sugerowana cytacja/Suggested citation:

Smętkowski, M., Celińska-Janowicz, D. (2018). Wybrane przestrzenne aspekty restrukturyzacji przemysłu w Europie Środkowo-Wschodniej przed kryzysem gospodarczym 2008 roku. Prace Komisji Geografii Przemysłu Polskiego Towarzystwa Geograficznego, 32(2), 38-58. https://doi.org/10.24917/20801653.322.3

\section{WSTĘP}

Jednym z kluczowych elementów transformacji systemowej krajów postsocjalistycznych była restrukturyzacja gospodarcza (Kukliński, Jałowiecki, 1991). Zastąpienie centralnego planowania zasadami wolnego rynku, których niezbywalnym elementem jest konkurencja, a o sukcesie działalności gospodarczej decyduje popyt na oferowane wyroby i usługi, wymusiło podniesienie racjonalności gospodarowania. Oznaczało to m.in. ograniczenie zasobochłonności gospodarki, co dotknęło zwłaszcza sektor przemysłowy, prowadząc do upadku wielu zakładów i ograniczenia znaczenia wybranych tradycyjnego branż.

Procesy restrukturyzacji krajów postsocjalistycznych zbiegły się w czasie z przekształceniami strukturalnymi obserwowanymi w skali globalnej (np. McMillan, Rodrik, 2011). Te ostatnie w uproszczeniu polegały na spadku roli przemysłu w gospodarkach krajów wysoko rozwiniętych na rzecz usług, przy jednoczesnym przenoszeniu znacznej części działalności przemysłowej za granicę do krajów słabiej rozwiniętych. W ciągu ostatniego ćwierćwiecza spadek znaczenia przemysłu w krajach Unii Europejskiej dotyczył przede wszystkim zatrudnienia, co związane było m.in. z postępującą mechanizacją i automatyzacją produkcji. Procesom tym nie zawsze towarzyszył analogiczny spadek roli sektora w zakresie wartości dodanej brutto, a w niektórych regionach krajów Europy Zachodniej poziom uprzemysłowienia gospodarki mierzony udziałem w tworzeniu wartości dodanej brutto wręcz wzrastał, przede wszystkim w branżach wiedzochłonnych, o wyższej wartości dodanej. Na tym tle kraje Europy Środkowo-Wschodniej prezentowały raczej niski potencjał przemysłowy, przy czym koncentrował się on przede wszystkim w branżach pracochłonnych (Rachwał, Wiedermann, Kilar, 2009).

Restrukturyzacja w krajach postsocjalistycznych objęła przede wszystkim duże państwowe zakłady przemysłowe, które były dominującą formą działalności gospodarczej w socjalistycznej gospodarce centralnie planowanej. Proces ten, poza likwidacją części dużych przedsiębiorstw państwowych, polegał także na przekształceniach własnościowych, które zazwyczaj przyjmowały formę prywatyzacji. Ponadto, borykające się z problemami natury makroekonomicznej państwa z reguły przestawały prowadzić aktywną politykę przemysłową. Należy jednak podkreślić, że różne formy pomocy publicznej dla nierentownych przedsiębiorstw były popularne aż do momentu wejścia tych krajów do Unii Europejskiej. Wówczas to interwencje tego typu zaczęły podlegać 
ograniczeniom polityki konkurencyjności UE, zakładającym warunkowość pomocy publicznej w połączeniu z jej ograniczeniem czasowym (zob. np. Wishlade, 2003), co miało wymuszać korzystne procesy restrukturyzacyjne (Wieloński, Bazydło, 2002; Rachwał, 2015).

Wpływ władz publicznych na procesy restrukturyzacyjne wiąże się $\mathrm{z}$ istotnym aspektem definicyjnym restrukturyzacji, a mianowicie z jej celowym charakterem (Tkocz, 2001). 0 ile bowiem na poziomie poszczególnych przedsiębiorstw działania restrukturyzacyjne mają co do zasady charakter celowy i zaplanowany, o tyle nie wszystkie procesy restrukturyzacyjne widoczne w skali regionalnej lub krajowej wynikają z intencjonalnych działań władz publicznych działających na tych szczeblach (Radło, Spałek, 2017). Dodatkowo wpływ na przebieg i tempo procesów restrukturyzacji przemysłu ma nie tylko określona polityka władz dotycząca tego sektora, ale także działania podejmowane $w$ innych obszarach, zmieniające warunki, $w$ jakich przemysł (i cała gospodarka) funkcjonuje (Zioło, 2010). Ponadto, w coraz bardziej zglobalizowanym świecie procesy te pozostają pod wpływem impulsów o charakterze zewnętrznym, takich jak: inwestycje zagraniczne (Domański, 2003; Radosevic, Rozeik, 2005; Poniatowska-Jaksch, 2006), kryzys gospodarczy (Haugh, Mourougane, Chatal, 2010; Rachwał, 2011c) czy zmiany czynników lokalizacji działalności przemysłowej (Kostrubiec, 2006; Olsen, 2006; Gierańczyk, 2008).

Restrukturyzacja przemysłu jako zagadnienie badawcze może być analizowana w trzech ujęciach: na poziomie poszczególnych przedsiębiorstw (poziom mikro), całej gospodarki (poziom makro) oraz w ujęciu sektorowym i regionalnym (poziom mezo) (Mikołajewicz, 1995; Rachwał, 2010; Rachwał, 2011a; Gierańczyk, Rachwał, 2012). Przekształcenia w skali makro i mezo są wypadkową zmian w funkcjonowaniu przedsiębiorstw przemysłowych i mają swój określony wymiar i wyraz przestrzenny (Stryjakiewicz, 1999; Zioło, 2008; Gierańczyk, 2014; Zioło, 2017). W tym ostatnim aspekcie szczególnie istotnym poziomem analiz jest skala regionalna, gdyż procesy restrukturyzacyjne $\mathrm{w}$ gospodarce, $\mathrm{w}$ tym $\mathrm{w}$ przemyśle, mogą przyczyniać się do pogłębiania różnic strukturalnych oraz w poziomie rozwoju między układami przestrzennymi (Gorzelak, 2003; Smętkowski, 2008; Ulbrych, 2014; Domański, 2015).

Artykuł ma na celu ocenę wybranych przestrzennych aspektów restrukturyzacji przemysłu w krajach Europy Środkowo-Wschodniej (EŚW) ${ }^{1}$ w latach 2002-2008, czyli przed światowym kryzysem gospodarczym. W szczególności zamierzeniem artykułu jest identyfikacja podregionów krajów EŚW, które odniosły relatywny sukces rozwojowy przy jednoczesnym wzroście znaczenia przemysłu w strukturze gospodarczej, a także wskazanie czynników tego sukcesu na przykładzie wybranych regionów.

W badaniach wykorzystano, po pierwsze, dane Eurostatu o wielkości i dynamice produktu regionalnego brutto na poziomie podregionalnym (NUTS3) oraz o strukturze gospodarczej i jej zmianach, zarówno w ujęciu wartości dodanej brutto, jaki liczby pracujących. Wybór poziomu podregionów jako obiektu badań nie był przypadkowy i wynikał z bardzo dużych zróżnicowań wewnątrzregionalnych, co było cechą charakterystyczną regionów poziomu NUTS2 w krajach EŚW (Smętkowski i in., 2011). Po drugie, dla wybranych podregionów przeprowadzono pogłębione badania w ramach studiów przypadku, obejmujące - poza analizą danych - również badania jakościowe w formie wywiadów pogłębionych z najważniejszymi interesariuszami rozwoju regionalnego i lokalnego.

${ }^{1}$ Badaniami objęto 10 postsocjalistycznych krajów makroregionu, które wstąpiły do Unii Europejskiej w 2004 roku (z wyjątkiem Chorwacji). 
W pierwszej części artykułu przedstawiono krajowy kontekst procesów restrukturyzacji przemysłu w krajach Europy Środkowo-Wschodniej. W kolejnej części pokazano regionalny wymiar restrukturyzacji przemysłu, koncentrując się na typologii podregionów nowych krajów członkowskich UE pod względem dynamiki wzrostu gospodarczego oraz zmiany udziału sektora przemysłowego w strukturze gospodarczej. Na tej podstawie podjęto próbę uproszczonej charakterystyki przypadków skrajnych dla poszczególnych krajów, koncentrując się na regionach rozwijających się w tempie szybszym od średniej krajowej, przy jednoczesnym wzroście znaczenia przemysłu. Spośród nich wybrano trzy podregiony, które objęto pogłębionymi badaniami, aby określić czynniki ich rozwoju, w tym rolę polityki intra- i interregionalanej (np. Gilowska, Gorzelak, Jałowiecki, Sobczak, 1998) w zachodzących procesach rozwojowych.

\section{ZMIANY STRUKTURALNE GOSPODAREK KRAJOWYCH}

Jednym z efektów restrukturyzacji gospodarczej była gwałtowna dezindustrializacja gospodarek krajów Europy Środkowo-Wschodniej (EŚW), dopasowująca je do postfordowskiego paradygmatu rozwoju (Gorzelak, 1995). Przejawiało się to zwłaszcza drastyczną redukcją zatrudnienia w przemyśle, ale przy zachowaniu relatywnie stabilnego udziału tego sektora w wartości dodanej brutto, co przekładało się na znaczący wzrost wydajności pracy (Rachwał, 2011b). Po 1995 roku (dla pierwszego okresu transformacji z reguły brak porównywalnych danych) w większości krajów nastąpił spadek udziału pracujących w przemyśle (ryc. 1a). Trajektoria zmian była przy tym dość zróżnicowana, choć tempo spadku znaczenia tego sektora w rynku pracy było względnie stałe. W największym stopniu dotyczyło to Słowenii, która jeszcze w połowie lat dziewięćdziesiątych miała największy ze wszystkich krajów odsetek pracujących w przemyśle, jak również Słowacji, Bułgarii, Litwy i Łotwy, a także Węgier. W efekcie na pozycję lidera wysunęły się Czechy, w których obserwowano okresowe wzrosty udziału pracujących w sektorze przemysłowym, a po 2003 roku udział ten był dość stabilny, na poziomie 29\%. W Rumunii z kolei znaczący spadek udziału pracujących w przemyśle dał się zaobserwować dopiero po 2006 roku, zaś w Estonii po 2004 roku. W pewnej mierze wyjątkowa była sytuacja Polski, która po 2002 roku odnotowywała niewielki, ale stały wzrost udziału pracujących w sektorze przemysłowym.

Trajektoria zmian udziału przemysłu w wartości dodanej brutto (WDB) była bardziej zróżnicowana (ryc. 1b). Dość znaczny spadek znaczenia przemysłu w tym ujęciu dotknął zwłaszcza Łotwę i Rumunię, ale proces ten uwidocznił się także w Słowenii i Estonii. W Czechach i Bułgarii sytuacja była natomiast stosunkowo stabilna. Na Litwie i Węgrzech następowały z kolei wyraźne zmiany trendu: w pierwszym przypadku wyrażone wyraźnym spadkiem po 2004 roku, podczas gdy w drugim przypadku spadek znaczenia przemysłu został zahamowany w 2004 roku. Podobna sytuacja miała miejsce na Słowacji i w Polsce, w których po 2002 roku odnotowano wyraźny wzrost udziału przemysłu w WDB.

Wydajność pracy w przemyśle w porównaniu z przeciętną wydajnością gospodarek krajowych była dość zróżnicowana. W przypadku Łotwy i Estonii była wyraźnie niższa, a na Łotwie obserwowany był ponadto jej bardzo silny spadek w latach 19972000. Najwyższa wydajność pracy w przemyśle, w porównaniu ze średnią krajową, cechowała Rumunię i Litwę, przy dość stabilnej sytuacji w pierwszym przypadku i dużych 
wahaniach w drugim. Do grupy krajów o wydajności pracy w przemyśle znacznie poniżej średniej krajowej dołączyła po 2002 roku także Słowacja. W pozostałych krajach EŚW widoczny był natomiast szybszy wzrost wydajności pracy w przemyśle w porównaniu z rozpatrywanymi łącznie pozostałymi sektorami, który jednak po 2007 roku uległ pewnemu zahamowaniu w związku z kryzysem gospodarczym.

Ryc. 1. Zmiana znaczenia przemysłu w gospodarce krajów Europy Środkowo-Wschodniej

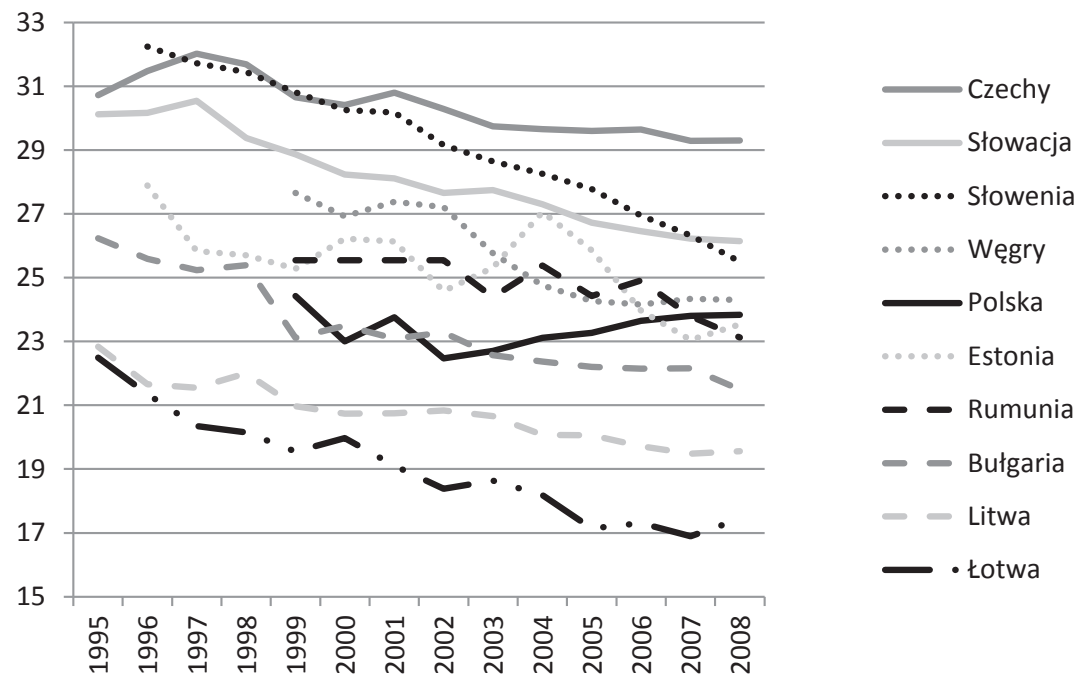

Zmiana udziału pracujących w przemyśle (\%)

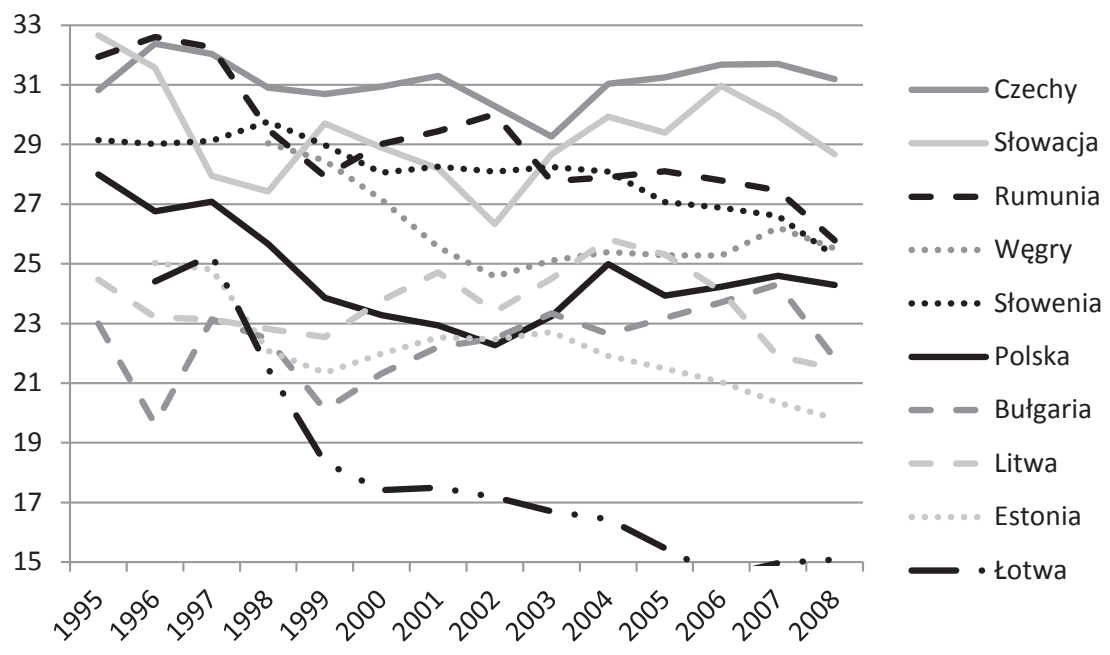

Zmiana udziału przemysłu w wartości dodanej brutto (\%) 


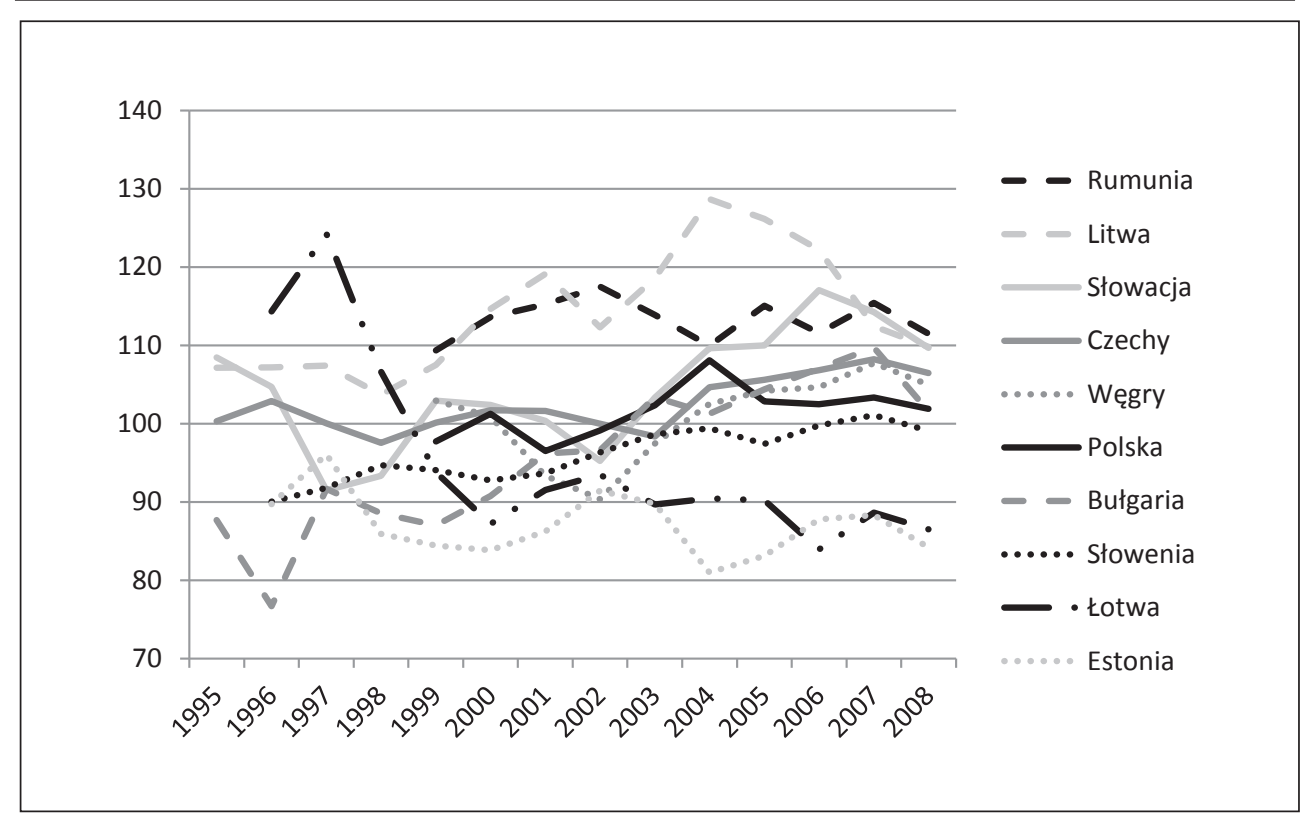

Zmiana produktywności (średnia krajowa = 100)

Źródło: opracowanie własne na podstawie danych Eurostatu (2017)

\section{RESTRUKTURYZACJA REGIONALNA}

Po 2002 roku² $^{2}$ większości regionów badanych krajów następował wyraźny spadek znaczenia przemysłu w gospodarce, widoczny zwłaszcza w obszarze zatrudnienia, jak również wartości dodanej brutto. Spadek ten był z reguły tym większy, im wyższy był udział przemysłu w gospodarce danego regionu (ryc. 2). Obserwowane korelacje nie były jednak wysokie $(\mathrm{r}=-0,30(\mathrm{p}<0,01) \mathrm{w}$ przypadku liczby pracujących i $\mathrm{r}=-0,15(\mathrm{p}$ $<0,01)$ w przypadku WDB), co oznacza, że istniało wiele regionów wyłamujących się z tej zależności. Nie zaobserwowano natomiast statystycznej zależności między zmianą roli przemysłu w gospodarce regionu a dynamiką jego tempa rozwoju w porównaniu ze średnią krajową.

Należy jednocześnie zauważyć, że zarówno w ramach całego makroregionu EŚW, jak i w poszczególnych krajach istniało bardzo duże zróżnicowanie pod względem znaczenia przemysłu w gospodarce (ryc. 3). W szerokim ujęciu, znacznie lepiej uprzemysłowione były regiony położone w zachodnich częściach poszczególnych krajów. Można zakładać, że jest to rezultatem wielu zjawisk, z których część jest silnie zakorzeniona w procesach długiego trwania (Braudel, 1970). Należą do nich m.in.:

- lepsza dostępność przestrzenna względem głównych rynków zbytu (głównym partnerem handlowym państw makroregionu są kraje EU15, a zwłaszcza Niemcy),

- lepsza dostępność przestrzenna dla inwestorów zagranicznych, w tym zwłaszcza z krajów sąsiadujących,

${ }^{2}$ Dla wcześniejszego okresu wiarygodność i porównywalność danych regionalnych w ujęciu międzykrajowym jest znacznie niższa, podobnie jak ich dostępność. 
Ryc. 2. Zmiana znaczenia przemysłu w gospodarce regionalnej w latach 2002-2008 (NUTS3) (oś pozioma) na tle stanu wyjściowego (udziału sektora w 2002 roku) (oś pionowa)

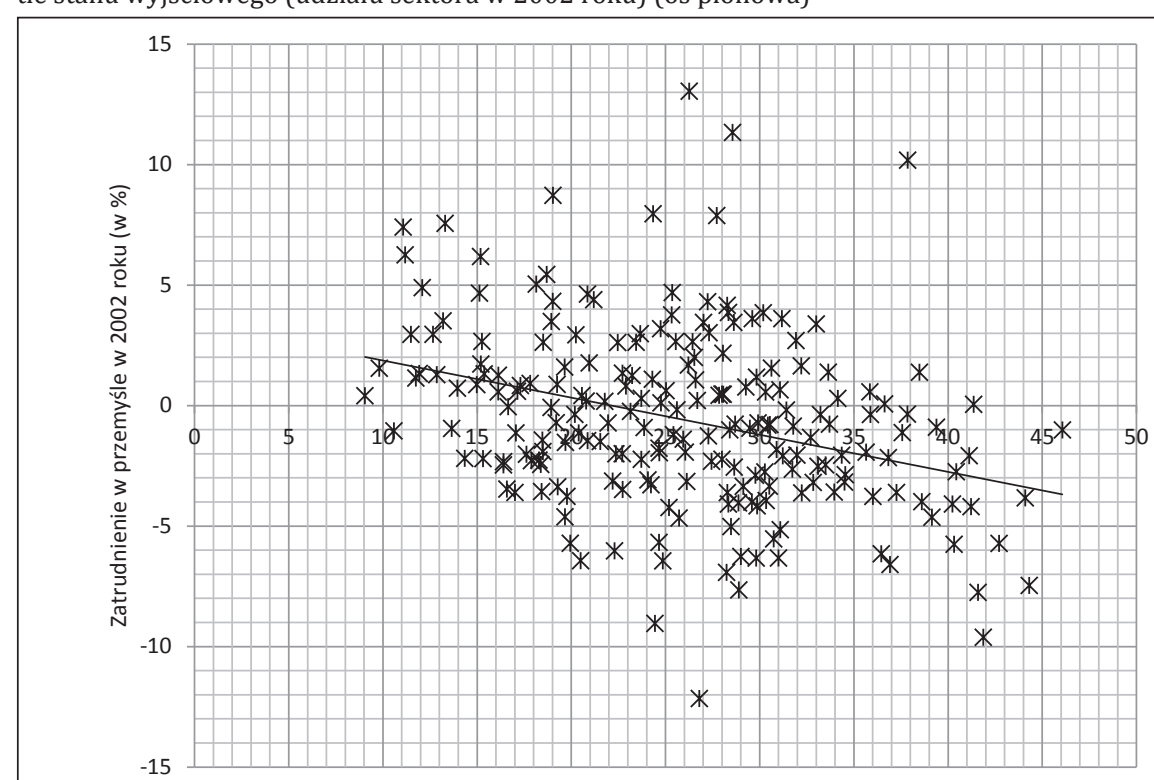

Zatrudnienie w przemyśle - zmiana w p.p. w latach 2002-2008

Pracujący

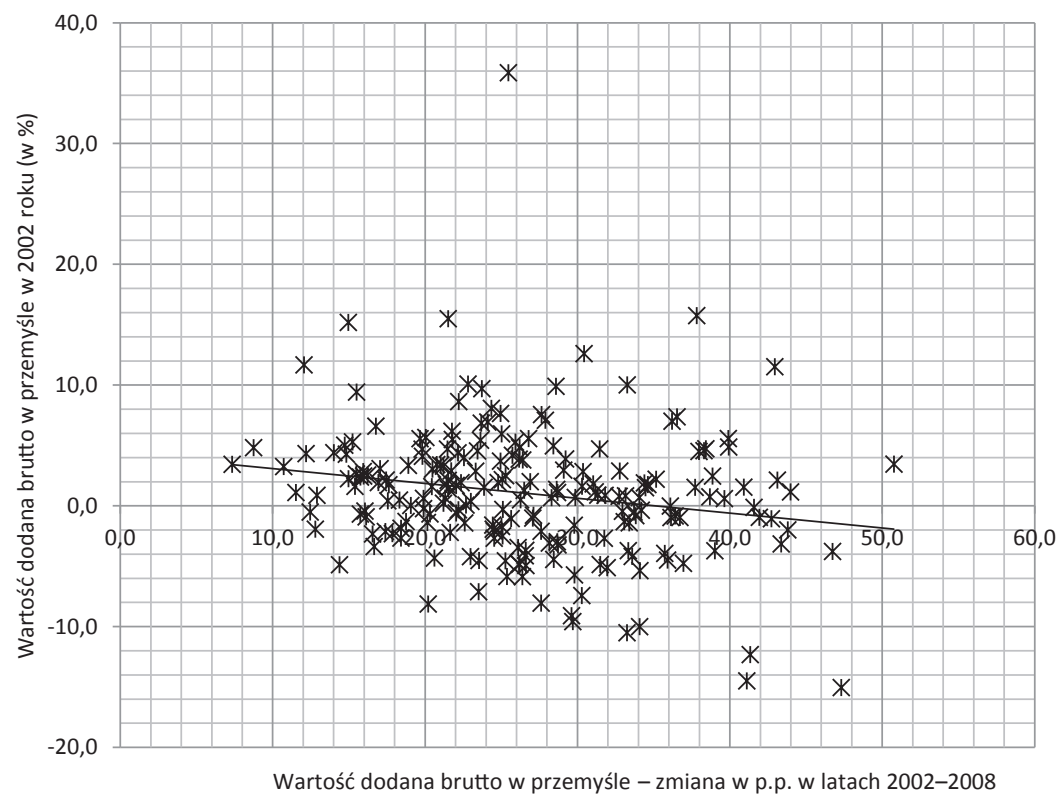

Wartość dodana brutto

Źródło: opracowanie własne na podstawie danych Eurostatu (2017) 
Ryc. 3. Udział przemysłu w strukturze gospodarczej regionów (NUTS3) w 2008 roku

Pracujący w przemyśle (w \%)

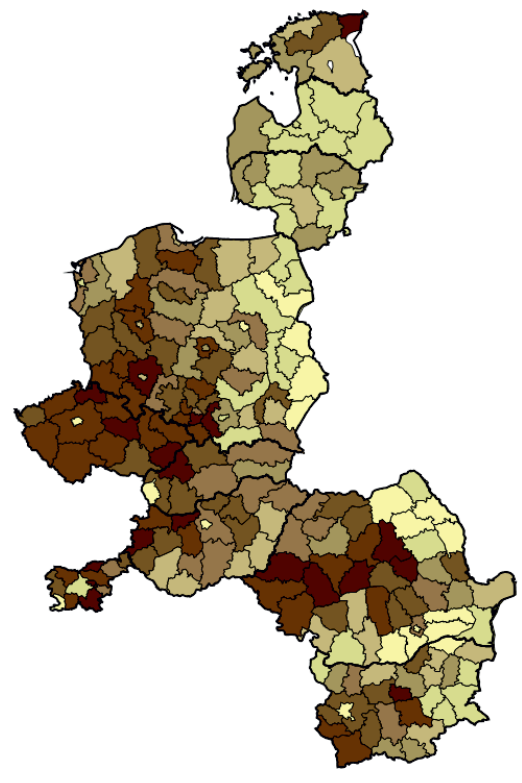

36,1 do 48,1 (19)

31,2 do 36,1 (32)

27,3 do $31,2(37)$

24,6 do $27,3(25)$

22,4 do $24,6(22)$

18,7 do 22,4 (28)

15,3 do $18,7(28)$

9,4 do $15,3(20)$
Udział wartości dodanej w przemyśle (w \%)

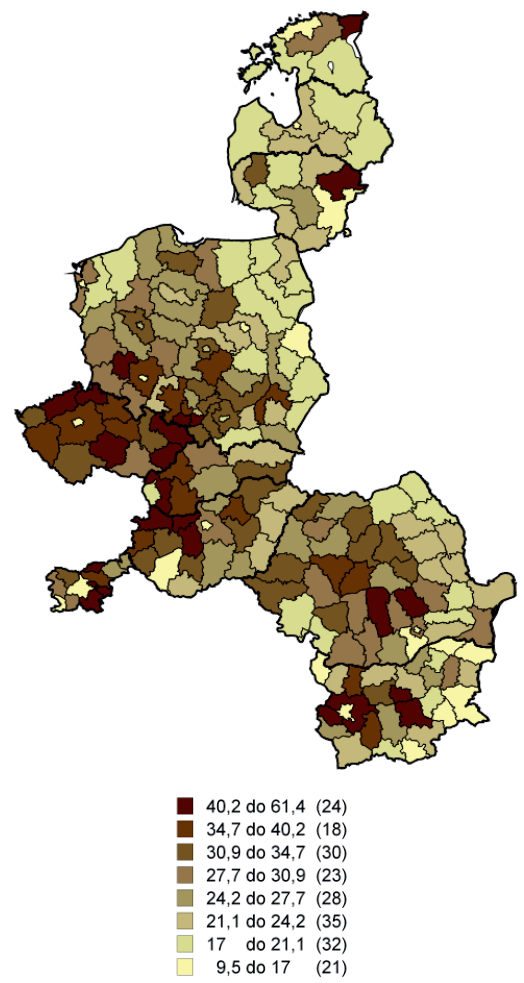

Źródło: opracowanie własne na podstawie danych Eurostatu (2017)

- istniejące tradycje przemysłowe ukształtowane w procesie przed- i powojennej industrializacji,

- dyfuzja innowacji z zachodu na wschód, wyrażająca się lepszym rozwojem sieci miejskiej w zachodnich częściach krajów, co mogło również sprzyjać rozwojowi bardziej nowoczesnych gałęzi przetwórstwa.

W ujęciu dynamicznym wzrost znaczenia przemysłu w zatrudnieniu w największym stopniu był widoczny w Polsce, za wyjątkiem podregionów należących do województw: śląskiego, łódzkiego, zachodniopomorskiego oraz podkarpackiego (ryc. 4a). Wzrost - choć dość niewielki - był też widoczny w części regionów czeskich, podczas gdy w równie silnie uprzemysłowionej Słowenii następował spadek znaczenia tego sektora w prawie wszystkich regionach. Zwiększenie znaczenia przemysłu można było zaobserwować również w zachodnich regionach Litwy i Łotwy (zwłaszcza nadmorskich) oraz w Rumunii, w tym zwłaszcza przy granicy z Węgrami i Serbią. Pod względem WDB (ryc. 4b), w stosunku do powyższych obserwacji, należy zauważyć wzrost znaczenia przemysłu w większości regionów czeskich, słowackich i węgierskich (z niewielkimi wyjątkami), a także w znacznej części Bułgarii. 
Ryc. 4. Zmiana struktury gospodarczej w latach 2002-2008

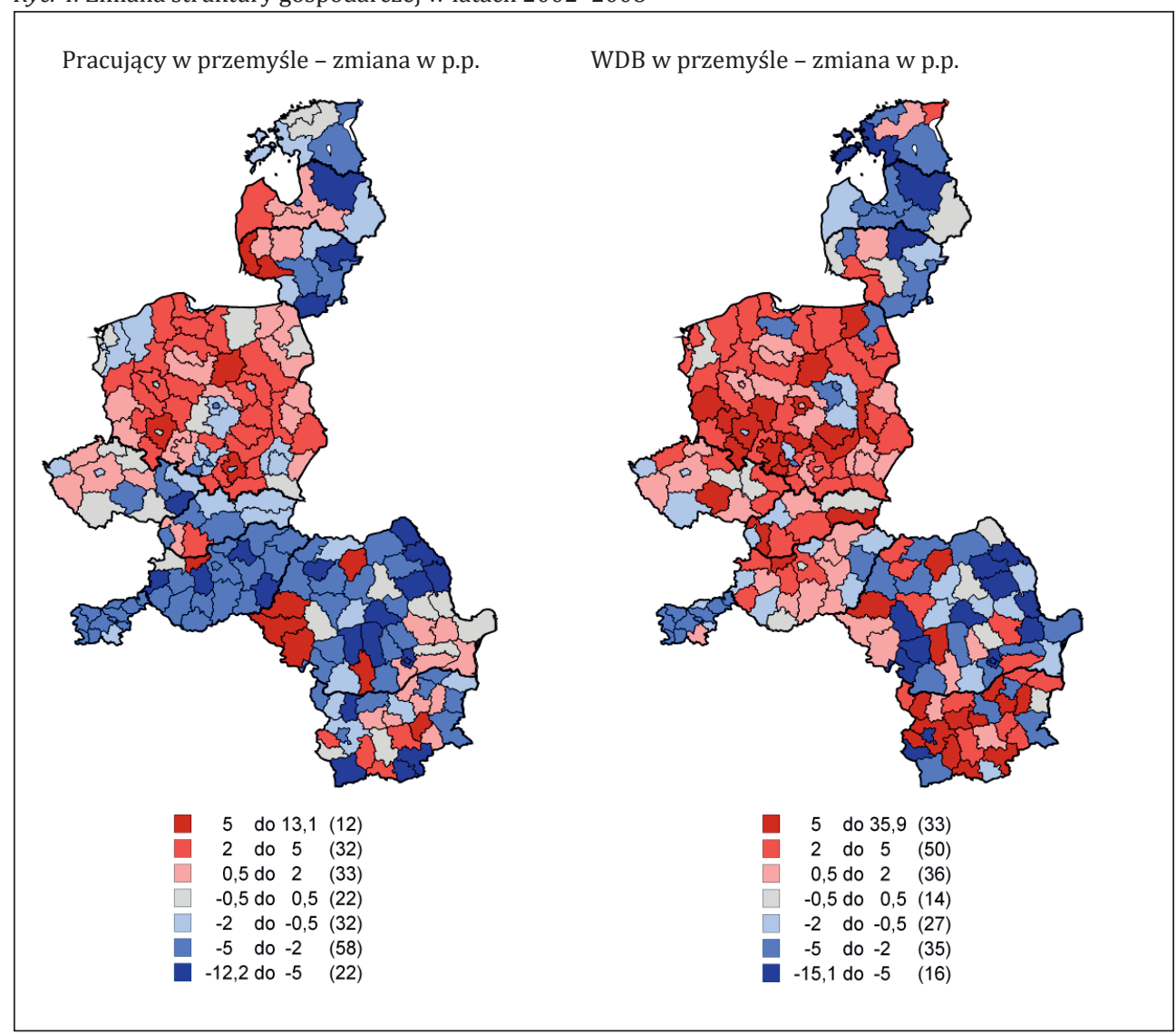

Źródło: opracowanie własne na podstawie danych Eurostatu (2017)

Analiza zmian udziału przemysłu w gospodarce i rynku pracy w stosunku do relatywnej zmiany pozycji danego regionu wobec średniej krajowej pozwala wyróżnić cztery sytuacje modelowe: a) poprawa pozycji regionu („rozwój”) i proces reindustrializacji b) poprawa pozycji regionu („rozwój”) i proces dezindustrializacji c) pogorszenie pozycji regionu (,regres”) i proces reindustrializacji oraz d) pogorszenie pozycji regionu („regres”) i proces dezindustrializacji (ryc. 5).

Pierwsza sytuacja, zwłaszcza w odniesieniu do WDB, była charakterystyczna przede wszystkim dla otoczenia sześciu ośrodków metropolitalnych w Polsce (Warszawy, Poznania, Trójmiasta, Wrocławia, Łodzi, Krakowa) oraz konurbacji górnośląskiej, a także wybranych regionów wydobycia i przetwórstwa surowców (np. legnicki, płocki czy bełchatowski). Do pewnego stopnia było to też widoczne w Rumunii w otoczeniu Bukaresztu, Klużu i Timiszoary, a także na Słowacji w otoczeniu Bratysławy, zaś w Bułgarii w niektórych regionach sąsiadujących z Sofią. W Czechach z kolei proces ten można było obserwować na Morawach (np. w starym okręgu przemysłowym w kraju morawsko-śląskim), a na Węgrzech w podregionie Komarom-Esztergom, sąsiadującym z Budapesztem, oraz w podregionie Miszkolca, który również stanowi przykład starego okręgu przemysłowego. Z kolei procesy reindustrializacji w zakresie WDB, ale przy 
Ryc. 5. Zmiana znaczenia przemysłu w strukturze gospodarczej na tle dynamiki rozwojowej w latach 20022008

Zmiana odsetka pracujących w przemyśle na tle dynamiki PKB zrelatywizowanej średnią krajową

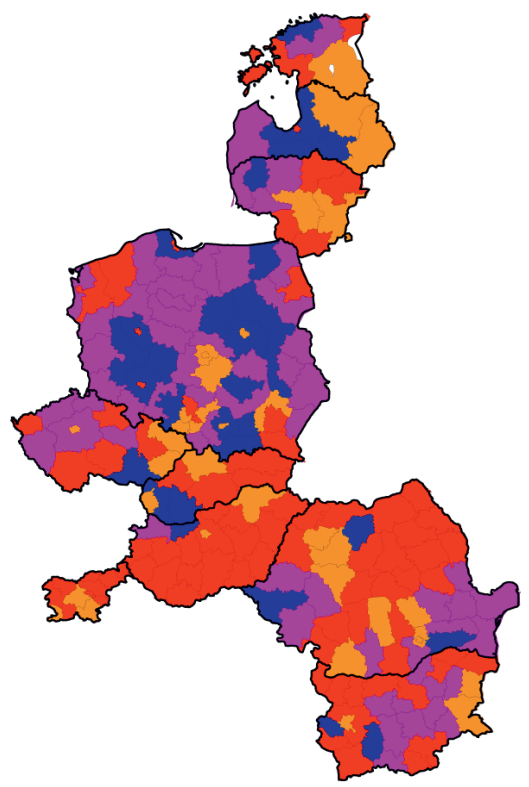

Zmiana udziału WDB w przemyśle na tle dynamiki PKB zrelatywizowanej średnią krajową

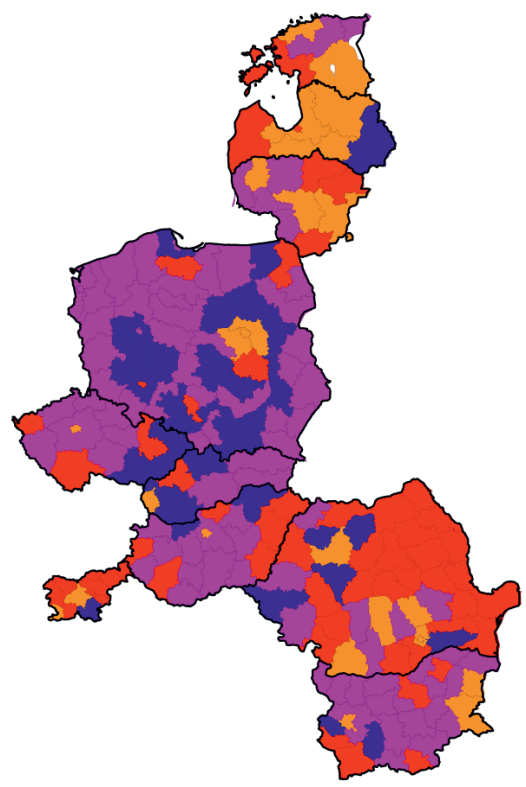

Regres - dezindustrializacja

Regres - industrializacja

Rozwój - dezindustrializacja

Rozwój - industrializacja

Źródło: opracowanie własne na podstawie danych Eurostatu (2017)

relatywnym pogorszeniu sytuacji regionu w stosunku do średniej krajowej, były charakterystyczne dla wielu regionów Polski, Czech, Słowacji, Węgier oraz Bułgarii.

Poprawa pozycji krajowej regionu przy zachodzącej jednocześnie dezindustrializacji była natomiast charakterystyczna prawie wyłącznie dla regionów NUTS3 dużych miast, które zajmowały ważne miejsce w krajowych systemach osadniczych. Znacznie częstsza była zaś sytuacja, w której procesy restrukturyzacji przemysłowej były niezakończone, a pozycja regionów w stosunku do średniej krajowej ulegała pogorszeniu. Sytuacja ta była charakterystyczna dla Rumunii i w mniejszym stopniu Bułgarii, a zatem dla państw, w których procesy transformacji i restrukturyzacji były w porównaniu do innych krajów opóźnione. Co interesujące, podobna sytuacja dotyczyła również Słowenii, w której - według niektórych autorów (np. Jaklič, Svetličič, 2003) - także widoczne było opóźnienie procesów restrukturyzacji przemysłu. Zmniejszanie roli przemysłu w WDB przy niskiej dynamice PKB było charakterystyczne tylko dla nielicznych regionów położonych w krajach wyszehradzkich. Natomiast w ujęciu liczby pracujących ten typ był reprezentowanych przez większości regionów Węgier i Słowacji. Z kolei w krajach bałtyckich sytuacja pod względem rozmieszczenia poszczególnych typów regionów była relatywnie najbardziej mozaikowa. 
Tab. 1. Wybrane przypadki skrajne pod względem dynamiki rozwoju i procesów reindustrializacji w poszczególnych krajach (w latach 2002-2008)

\begin{tabular}{|c|c|c|c|c|c|c|c|}
\hline \multirow[b]{2}{*}{ Kraj } & \multirow{2}{*}{ Region } & \multirow{2}{*}{$\begin{array}{c}\text { Zmiana } \\
\text { PKB per } \\
\text { capita } \\
\text { względem } \\
\text { średniej } \\
\text { krajowej } \\
\text { (w p.p.) }\end{array}$} & \multicolumn{2}{|c|}{$\begin{array}{l}\text { Udział przemysłu } \\
\text { w } 2002 \text { roku }\end{array}$} & \multicolumn{2}{|c|}{$\begin{array}{c}\text { Zmiana udziału } \\
\text { przemysłu w latach } \\
\text { 2002-2008 (w p.p.) }\end{array}$} & \multirow[b]{2}{*}{ Typ regionu } \\
\hline & & & pracujący & $\begin{array}{l}\text { wartość } \\
\text { dodana } \\
\text { brutto }\end{array}$ & pracujący & $\begin{array}{l}\text { wartość } \\
\text { dodana } \\
\text { brutto }\end{array}$ & \\
\hline Estonia & $\begin{array}{l}\text { Północna } \\
\text { Estonia }\end{array}$ & 2,9 & 20,8 & 17,8 & 0,2 & $-2,3$ & $\begin{array}{l}\text { region dużego } \\
\text { miasta }\end{array}$ \\
\hline Czechy & $\begin{array}{l}\text { Kraj } \\
\text { południowo- } \\
\text { morawski } \\
\end{array}$ & 2,5 & 28,0 & 28,7 & 0,5 & 1,1 & $\begin{array}{l}\text { region dużego } \\
\text { miasta }\end{array}$ \\
\hline Rumunia & Timisoara & 13,1 & 27,7 & 31,3 & 7,9 & 0,9 & $\begin{array}{l}\text { region dużego } \\
\text { miasta }\end{array}$ \\
\hline Łotwa & Pieriga & 11,8 & 16,1 & 26,2 & 0,6 & $-4,8$ & $\begin{array}{l}\text { obszar } \\
\text { metropolitalny }\end{array}$ \\
\hline Bułgaria & Pernik & 30,3 & 27,3 & 25,5 & 3,0 & 35,9 & $\begin{array}{l}\text { makroregion } \\
\text { metropolitalny }\end{array}$ \\
\hline Słowacja & Kraj trnawski & 14,9 & 30,3 & 36,5 & 0,6 & 7,4 & $\begin{array}{l}\text { makroregion } \\
\text { metropolitalny }\end{array}$ \\
\hline Węgry & $\begin{array}{l}\text { Komárom- } \\
\text {-Esztergom }\end{array}$ & 13,5 & 37,8 & 42,9 & 10,2 & 11,5 & $\begin{array}{l}\text { region } \\
\text { metropolitalny/ } \\
\text { stary okręg } \\
\text { przemysłowy }\end{array}$ \\
\hline Łotwa & Semigalia & 3,9 & 16,1 & 26,2 & 1,3 & $-4,8$ & $\begin{array}{l}\text { makroregion } \\
\text { metropolitalny }\end{array}$ \\
\hline Słowenia & $\begin{array}{l}\text { Słowenia } \\
\text { Płudniowo- } \\
\text {-Wschodnia }\end{array}$ & 0,4 & 37,6 & 40,9 & $-1,1$ & 1,6 & $\begin{array}{l}\text { makroregion } \\
\text { metropolitalny }\end{array}$ \\
\hline Czechy & $\begin{array}{l}\text { Kraj } \\
\text { morawsko- } \\
\text {-śląski }\end{array}$ & 6,9 & 35,6 & 38,4 & $-1,9$ & 4,7 & $\begin{array}{l}\text { stary okręg } \\
\text { przemysłowy }\end{array}$ \\
\hline Węgry & $\begin{array}{l}\text { Borsod-Abaúj- } \\
\text { Zemplén }\end{array}$ & 0,8 & 29,1 & 32,7 & $-3,4$ & 0,8 & $\begin{array}{l}\text { stary okręg } \\
\text { przemysłowy }\end{array}$ \\
\hline Litwa & \begin{tabular}{|l} 
Okręg \\
telszański \\
\end{tabular} & 0,5 & 23,2 & 36,9 & 1,2 & $-4,7$ & surowcowy \\
\hline Polska & $\begin{array}{l}\text { Legnicko- } \\
\text {-głogowski }\end{array}$ & 31,2 & 30,2 & 37,8 & 3,8 & 15,8 & surowcowy \\
\hline Polska & $\begin{array}{l}\text { Ciechanowsko- } \\
\text {-płocki }\end{array}$ & 16,5 & 15,2 & 23,7 & 6,2 & 9,7 & surowcowy \\
\hline Słowacja & Kraj żyliński & 5,4 & 30,4 & 29,8 & $-0,8$ & 0,7 & inny \\
\hline Bułgaria & Pazardżik & 2,5 & 25,5 & 21,5 & 2,7 & 15,5 & inny \\
\hline Rumunia & Alba & 9,6 & 34,3 & 32,8 & $-2,1$ & 2,9 & inny \\
\hline
\end{tabular}

Źródło: opracowanie własne na podstawie danych Eurostatu (2017)

Na podstawie przedstawionej typologii można wskazać regiony, które mogą być interesującymi przykładami udanej restrukturyzacji przemysłu, tzn. takie, w których rosło znaczenie przemysłu w gospodarce, przy jednoczesnym wzroście wydajności pracy i poprawie ich pozycji pod względem PKB per capita względem średniej krajowej. Analiza kontekstowa obserwacji skrajnych w obrębie poszczególnych krajów w zestawieniu z wcześniejszymi mapami pozwala przedstawić pewne uproszczone generalizacje (tab. 1). 
Po pierwsze, proces reindustrializacji był charakterystyczny dla bezpośredniego otoczenia dużych miast, zarówno tego bliższego, czyli wchodzącego w skład ich obszarów metropolitalnych, jak i dalszego, zawierającego się w ramach makroregionów metropolitalnych. W regionach dużych miast proces ten zachodził z reguły tylko w specyficznym kontekście wynikającym z objęcia przez region NUTS3 zarówno miasta, jak i jego obszaru funkcjonalnego (np. Tallin, Brno czy Timiszoara). Kolejnym rodzajem regionów spełniających założone warunki były wybrane regiony wydobycia lub przetwórstwa surowców (np. płocki i legnicki w Polsce oraz Telsze na Litwie). Ponadto, w skład tej grupy weszły również wybrane stare okręgi przemysłowe, takie jak region Ostrawy czy Miszkolca, które przynajmniej w pewnym stopniu poradziły sobie z restrukturyzacją przemysłu. Natomiast pozostałe regiony, niesklasyfikowane we wspomnianych typach, charakteryzowały się z reguły stosunkowo dobrą dostępnością transportową, wyrażającą się położeniem w korytarzach głównych dróg, w tym autostrad.

Z tej grupy do pogłębionych badań w ramach studiów przypadku wybrano trzy regiony, które należały do różnych typów, czyli Komárom-Esztergom na Węgrzech (największe miasto Tatabanya), kraj morawsko-śląski w Czechach (największe miasto Ostrawa) oraz region Alba w Rumunii (największe miasto Alba Iulia). Przeprowadzono w nich zarówno dodatkowe badania ilościowe, jak i jakościowe, polegające na zebraniu wywiadów pogłębionych z interesariuszami rozwoju regionalnego ${ }^{3}$.

\section{RESTRUKTURYZACJA REGIONALNA - STUDIA PRZYPADKU}

Wybrane do badań regiony administracyjne były zamieszkane przez odpowiednio: 311 tys. osób (okręg Komárom-Esztergom, największe miasto Tatabanya 72 tys.), 371 tys. (okręg Alba, największe miasto Alba Iulia 66 tys.) oraz $1 \mathrm{mln} 243$ tys. (kraj morawsko-śląski, największe miasto Ostrawa 310 tys.). Pierwszy z nich reprezentował typ starego regionu przemysłowego położonego w regionie metropolitalnym $\mathrm{Bu}$ dapesztu, którego restrukturyzacja na skutek wyczerpania złóż węgla rozpoczęła się jeszcze w latach osiemdziesiątych. Drugi z nich był regionem położonym w centralnej części Rumunii, graniczącym z najważniejszym ośrodkiem miejskim tego makroregionu, czyli Klużem. Trzeci region stanowił klasyczny przykład starego okręgu przemysłowego, którego restrukturyzacja rozpoczęła się wraz z procesami transformacji w latach dziewięćdziesiątych.

\section{Trajektoria rozwojowa i restrukturyzacja}

Pod względem poziomu rozwoju, wyrażonego w PKB na 1 mieszkańca w euro, najsłabiej rozwinięty był region rumuński - dochód per capita prawie dwukrotnie niższy niż regionów czeskiego i węgierskiego (ryc. 6). Natomiast w latach 1995-2010 ścieżka rozwojowa wszystkich trzech regionów była podobna. Do 2000 roku PKB per capita wyrażony w euro dość wolno rósł, by później - wraz z perspektywą członkostwa w UE - znacząco przyśpieszyć, zwłaszcza w przypadku regionu Komárom-Esztergom; w dwóch pozostałych dynamika znacząco wzrosła dopiero po 2004 roku. Najwyższe poziomy rozwoju odnotowano na przełomie 2007 i 2008 roku, zaś w kolejnych latach,

${ }^{3}$ Badania jakościowe przeprowadzono w dwóch turach, czyli w latach 2009-2010 (Smętkowski, 2013) oraz w latach 2012-2013: Alba Iulia (Constantin, Gosin, 2014), Komarem-Esztergom (Scott, Szalai, 2014), kraj morawsko-śląski (Blažek, Bečicová, 2014). 
Ryc. 6. Dynamika PKB per capita (w euro) w latach 1995-2010

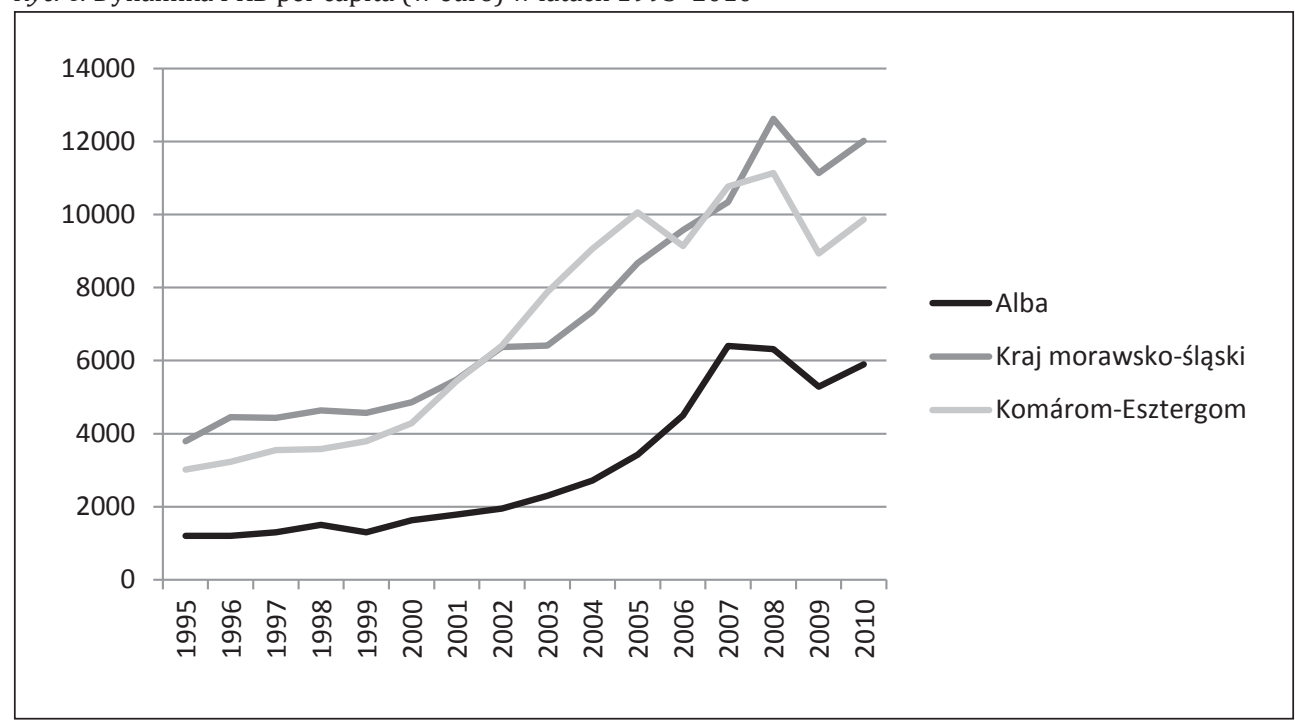

Źródło: opracowanie własne na podstawie Eurostatu (2017)

w efekcie kryzysu, nastąpił spadek PKB per capita w euro, który został trwale zahamowany w 2010 roku.

Sytuacja wyglądała inaczej w przypadku odniesienia dynamiki rozwoju tych regionów do średniej krajowej (ryc. 7). 0 ile bowiem w 1995 roku poziom ich rozwoju wynosił około 90\% średniej danego kraju, o tyle po 1999 roku nastąpiło znaczące zróżnicowanie sytuacji. Dotyczyło to zwłaszcza wyraźnej utraty pozycji przez region Ostrawy, co zostało zahamowane dopiero na przełomie 2004 i 2005 roku, a po odbiciu PKB per capita osiągnął poziom ok. 85\% średniej. Natomiast regiony Tatabanii i Alby Iulii, po spadku w drugiej połowie lat dziewięćdziesiątych, systematycznie poprawiały swoją pozycję względem średniej, osiągając poziom z 1995 roku odpowiednio w roku 2002 i 2003. W późniejszym okresie nastąpił ich bardzo szybki wzrost, w przypadku Komárom-Esztergom szczególnie widoczny w latach 2003-2005, a w przypadku regionu Alby w latach 2006-2007, co skutkowało przekroczeniem krajowego PKB per capita o kilkanaście p.p. Kryzys w 2008 roku doprowadził do pewnej utraty tej przewagi (w przypadku regionu węgierskiego pierwszy spadek nastąpił już w 2006 roku), ale odbicie, które miało miejsce w 2010 roku, ponownie podniosło PKB na mieszkańca powyżej średniej.

Poprawa pozycji w odniesieniu do średniej wynikała w znacznej mierze z poprawy wydajności pracy w sektorze przemysłowym (ryc. 8), co było dobrze widoczne w przypadku kraju morawsko-śląskiego oraz regionu Tatabanii. Słabiej widoczne było to zjawisko w przypadku rumuńskiej Alby, ale tu również wydajność pracy w przemyśle znacząco przekraczała średnią krajową, za wyjątkiem lat 2002-2004.

Jednocześnie w przypadku regionów Alby i Komárom-Esztergom wzrost gospodarczy zachodził w warunkach relatywnie stałej stopy bezrobocia (według BAEL), która była zbliżona do poziomu ok. 5\% (ryc. 9). Może to oznaczać, że rozwój gospodarczy był w głównej mierze efektem wzrostu produktywności i przesunięć międzysektorowych do bardziej wydajnych branż gospodarki. W przypadku regionu węgierskiego należy 
Ryc. 7. PKB per capita w odniesieniu do średniej krajowej (100) w latach 1995-2010

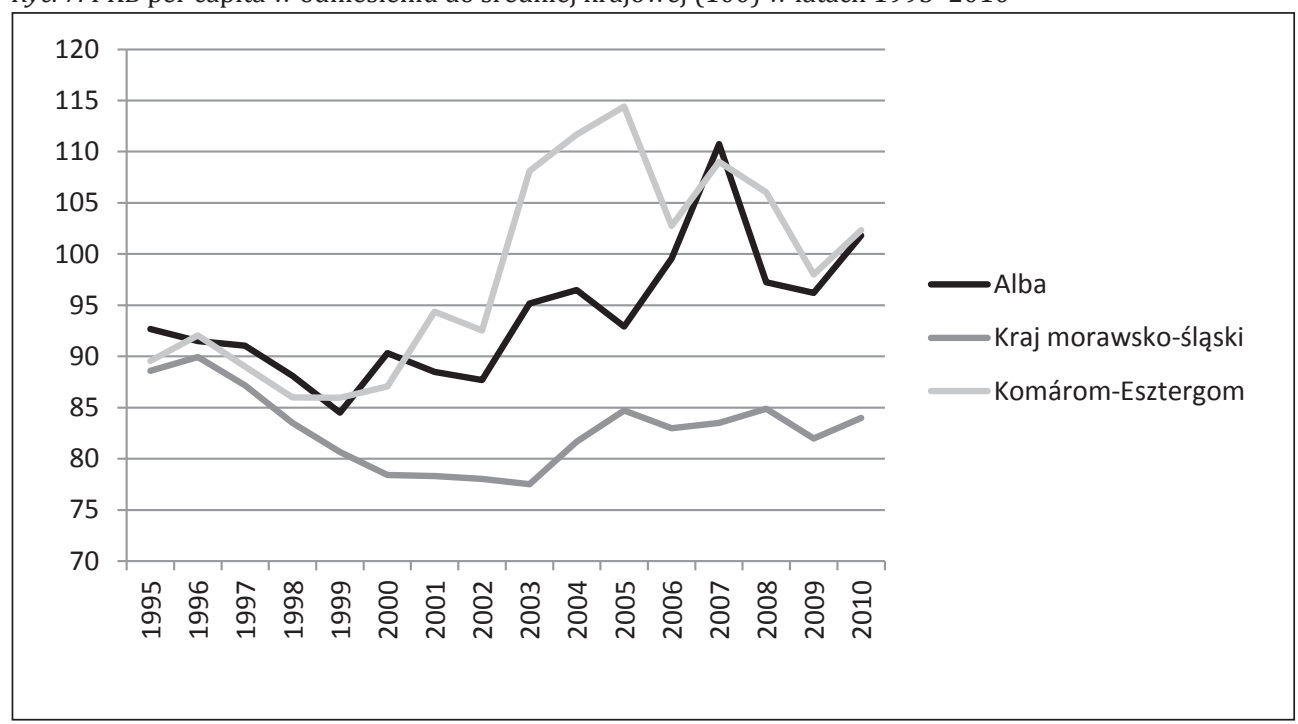

Źródło: opracowanie własne na podstawie Eurostatu (2017)

Ryc. 8. Wydajność pracy w przemyśle na tle średniej krajowej (100) w latach 2000-2008

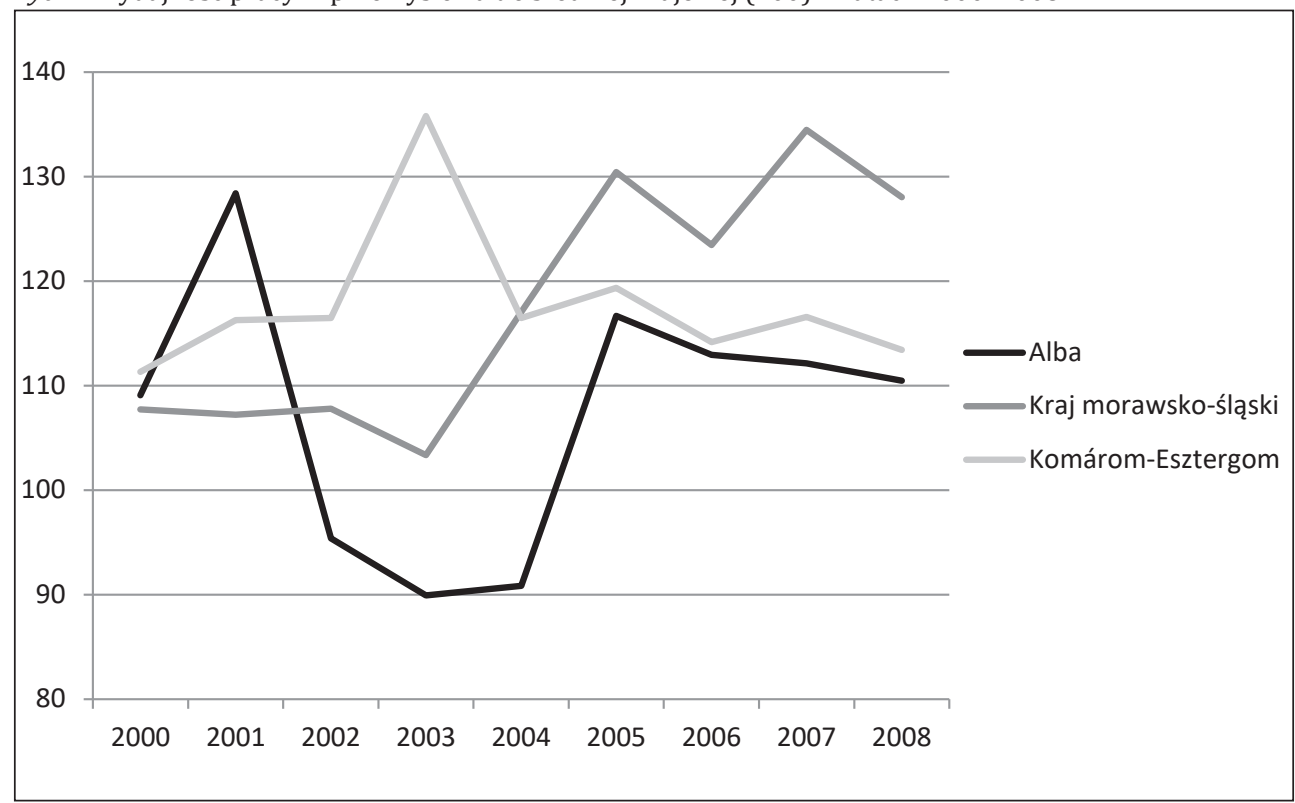

Źródło: opracowanie własne na podstawie Eurostatu (2017)

jednak zwrócić uwagę na wyraźny wzrost bezrobocia w efekcie kryzysu gospodarczego zapoczątkowanego w 2008 roku. Natomiast w regionie Ostrawy przyśpieszenie dynamiki gospodarczej po 2005 roku spowodowało wyraźny spadek stopy bezrobocia, który jednak - podobnie jak przypadku regionu węgierskiego - został zahamowany kryzysem gospodarczym. 
Ryc. 9. Stopa bezrobocia (wg BAEL) (w \%) w latach 1999-2010

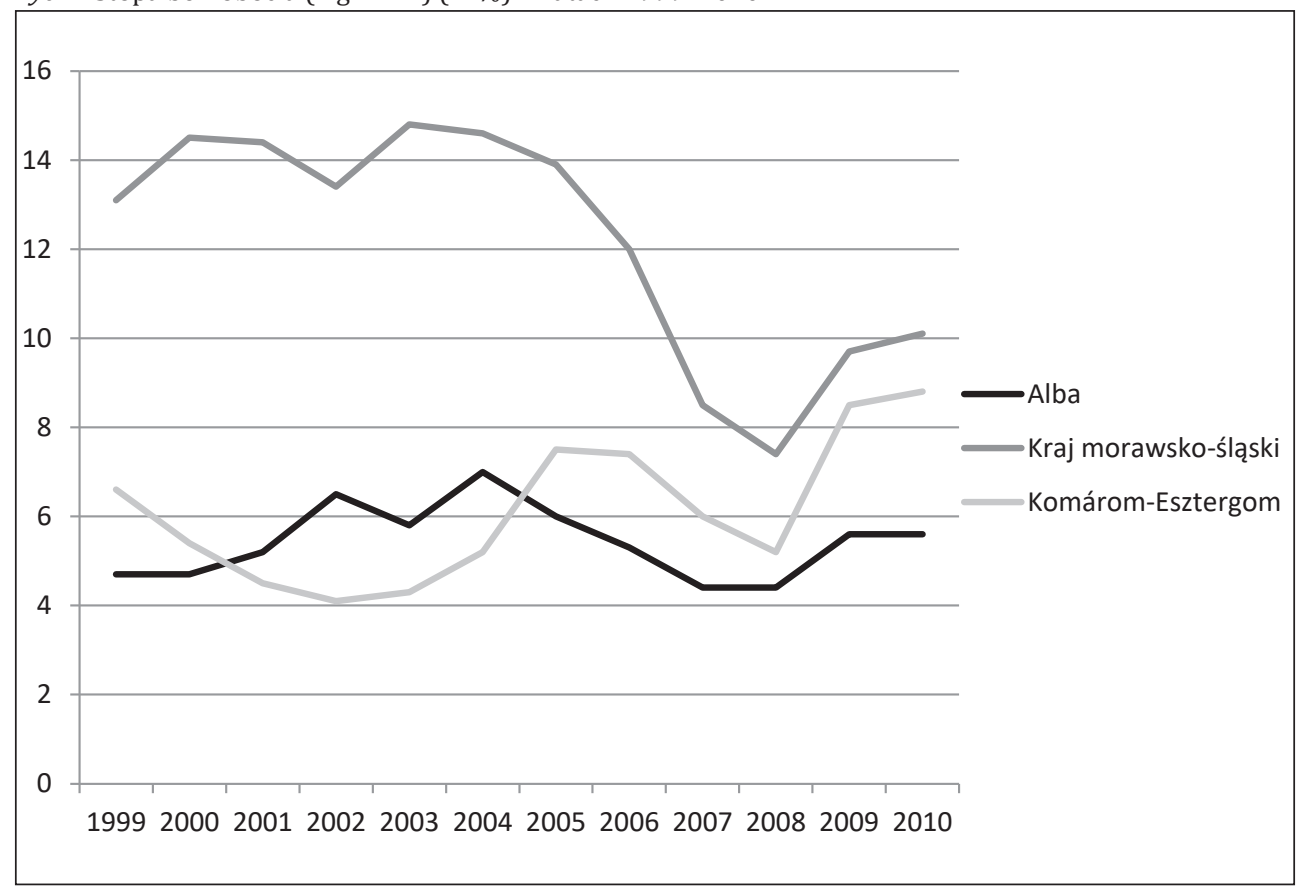

Źródło: opracowanie własne na podstawie Eurostatu (2017)

\section{Czynniki rozwojowe}

Na podstawie przeprowadzonych badań jakościowych ${ }^{4}$ można stwierdzić, że głównym czynnikiem rozwoju badanych regionów był napływ kapitału zagranicznego, co było szczególnie dobrze jest widoczne w regionach węgierskim i czeskim oraz trochę słabiej w rumuńskim. Jednym z elementów, które przyciągały inwestorów, były zachęty w postaci parków przemysłowych oferujących uzbrojone tereny inwestycyjne i zwolnienia podatkowe (największy park przemysłowy powstał na Węgrzech przy autostradzie M1 między Budapesztem i Wiedniem w regionie Komárom-Esztergom). Ważną rolę odegrały również decyzje koncernów motoryzacyjnych - Isuzu, który zainwestował w Esztergomie, i Hyundaia, który zlokalizował się w Ostrawie. Nowe fabryki samochodów wpłynęły na lokalizacje w ich sąsiedztwie licznych kooperantów, choć nierzadko łańcuch dostawców wykraczał nie tylko poza granicę regionów NUTS3, ale również granic państwowych. W Albie napływ zewnętrznych inwestycji nie był tak spektakularny i dotyczył raczej tradycyjnych branż - przemysłu lekkiego (drzewnego i tekstylnego) i maszynowego. Czynniki skłaniające inwestorów do zainwestowania kapitału w badanych regionach były dość różnorodne. W Ostrawie znaczenie miały czynniki aglomeracji, czyli łatwy dostęp do dużego rynku pracy wykwalifikowanych pracowników przemysłowych, ale również możliwości kooperacyjne i dobrze rozwinięta infrastruktura techniczna. Region Komárom-Esztergom również dysponował podobnymi zaletami,

\footnotetext{
${ }^{4}$ Badania jakościowe objęły m.in. analizę dokumentów strategicznych oraz wywiady pogłębione z głównymi interesariuszami rozwoju (por. Smętkowski, 2013; Blažek, Bečicová, 2014; Constantin, Goschin, 2014; Scott, Szalai, 2014).
} 
a co więcej jego atutem było bliskie sąsiedztwo Budapesztu i związane z nim korzyści w postaci wykwalifikowanej kadry i rynku zbytu. W przypadku Alby znaczenie miały dostępne zasoby naturalne w powiązaniu z bardzo niskimi kosztami pracy. Ten ostatni czynnik, w połączeniu z wysokimi kwalifikacjami siły roboczej, był bardzo ważnym elementem przyciągającym inwestorów zewnętrznych we wszystkich przypadkach.

O ile czynniki zewnętrzne odgrywały kluczową rolę w rozwoju badanych regionów, o tyle ich potencjał rozwoju endogenicznego był dość ograniczony. Stopień zaawansowania technologicznego przemysłu wciąż można uznać - z pewnymi wyjątkami - za średni lub niski, a wykorzystanie lokalnego potencjału badawczo-rozwojowego było niewielkie. Największy potencjał pod tym względem istniał w Ostrawie, w związku z lokalizacją w tym mieście politechniki oraz parku technologicznego. Kolejną słabą stroną był dość słabo rozwinięty sektor małych i średnich przedsiębiorstw (za wyjątkiem regionu Alba, w którym miały one znaczący udział w sukcesie rozwojowym), które z reguły nie były w stanie nawiązać współpracy z transnarodowymi kooperacjami. Także proces tworzenia klastrów napotykał na liczne bariery, ale z pewnymi wyjątkami, którym był np. rozwijający się w Ostrawie klaster motoryzacyjny i ICT.

Do stosunkowo istotnych mankamentów obserwowanego modelu rozwoju badanych regionów należy zatem stosunkowo małe zakorzenienie inwestycji zagranicznych w układach lokalnych i regionalnych, co w warunkach wzrostu kosztów pracy i dekapitalizacji majątku zakładów przemysłowych może w przyszłości skłaniać zagraniczne firmy do relokacji do krajów lub regionów o niższych kosztach pracy. Ponadto w rozwoju endogenicznym przeszkadzała stosunkowo niska jakość życia, jaką mogą zaoferować badane regiony. W najmniejszym stopniu dotyczy to regionu węgierskiego, którego obrzeża znalazły się w strefie procesów suburbanizacyjnych Budapesztu. Jedną z przyczyn są wciąż nierozwiązane problemy środowiskowe związane z poprzednim modelem rozwoju.

\section{Władze lokalne i regionalne, uwarunkowania instytucjonalne i model zarządzania}

W sukcesie gospodarczym badanych regionów ważną rolę odegrały lokalne i regionalne polityki oraz zaangażowanie władz w proces przyciągania inwestorów zagranicznych. Przyjmowało to najczęściej wspomnianą wcześniej formę tworzenia parków przemysłowych oferujących, poza infrastrukturą techniczną, również szereg zachęt o charakterze finansowym. Aktywne pod tym względem były również agencje rozwoju, które starały się minimalizować uciążliwości biurokratyczne związane z procesem inwestycyjnym. Ponadto władze lokalne wykazywały aktywność we wspieraniu procesów prywatyzacji istniejących przedsiębiorstw. Rozwój infrastruktury technicznej wspomagany był prowadzeniem działań miękkich w zakresie szkoleń pracowników oraz rozwoju systemu szkolnictwa dopasowanego do potrzeb rynku pracy, co objęło m.in. wzmacnianie szkolnictwa średniego znajdującego się w gestii samorządów lokalnych i regionalnych, a także zabieganie o rozwój szkolnictwa wyższego.

Wszystkie badane miasta miały strategie rozwoju, które były uzupełniane strategiami rozwoju regionów na poziomie NUTS2. W obydwu typach strategii wskazywano równie często na działania na rzecz zwiększenia konkurencyjności danego układu terytorialnego, jak i na te mające poprawić jakość życia mieszkańców. W działaniach dotyczących konkurencyjności coraz większą wagę przywiązywano do zagadnienia 
innowacyjności, ale dość często odnośne cele były słabo zoperacjonalizowane. Ponadto podkreślano znaczenie poprawy jakości kapitału ludzkiego, co starano się osiągnąć przez rozwój i wzrost jakości szkolnictwa oraz kształcenia ustawicznego. Ważne miejsce w większości strategii zajmowały sektor MSP oraz działania mające na celu tworzenie warunków do powstawania nowych i rozwoju istniejących firm. Wśród kierunków rozwoju wskazywano również rozwój funkcji ponadlokalnych, w tym administracyjnych, a także turystyki. W większości badanych strategii można było zarysować dość wyraźną i klarowną wizję przyszłego rozwoju. Respondenci z reguły podkreślali zaangażowanie i dość dużą skuteczność władz miast w realizacji opracowanych planów, czemu ich zdaniem sprzyjała dostępność finansowania zewnętrznego, w tym przede wszystkim środków polityki spójności UE.

Należy zauważyć, że o ile powyższe działania są dość szeroko rozpowszechnione, o tyle o sukcesie tych a nie innych regionów zdecydowało ich szybkie podjęcie - jeszcze w pierwszej fazie transformacji - co było widoczne w przypadku regionu węgierskiego i rumuńskiego. Działania te uległy opóźnieniu w przypadku Ostrawy, która jednak dysponowała innymi znaczącymi atutami, związanymi m.in. z efektami aglomeracji. Spowodowały one, że mimo późnego włączenia się do wyścigu o inwestorów zewnętrznych Ostrawa osiągnęła pod tym względem sukces. Mimo to regionowi wciąż nie udało się nadrobić zaległości powstałych w pierwszym okresie transformacji.

Bardzo istotną kwestią podkreślaną przez respondentów była dobrze rozwinięta współpraca władz samorządowych: zarówno wertykalna, jak i horyzontalna. Instytucje publiczne różnych szczebli były otwarte i chętne do współpracy i wdrażania wspólnych strategii oraz przedsięwzięć (np. regionalny bank w Ostrawie). Stopień zaangażowania miejscowych środowisk biznesowych i naukowych, podobnie jak organizacji społecznych, był jednak dość zróżnicowany i daleki od optymalnego.

\section{Interwencja zewnętrzna}

Interwencja zewnętrzna realizowana w badanych regionach miała również istotne znaczenie dla osiągnięcia przez nie sukcesu. Odnosi się to zwłaszcza do rozwoju infrastruktury transportowej o znaczeniu ogólnokrajowym, co miało miejsce przede wszystkim na Węgrzech (autostrada) i w Czechach (autostrada i linia kolejowa), choć również region rumuński jest położony w korytarzu transportowym drogi krajowej numer 1, łączącej Bukareszt z granicą węgierską. W tym ostatnim przypadku gorsza pozycja lokalizacyjna kompensowana było dość preferencyjną polityką o charakterze regionalnym, w tym m.in. lokalizacją agencji zarządzającej wdrażaniem programu regionalnego na poziomie NUTS2. Pod tym względem natomiast słabo wypadał region węgierski, który nie ma uprzywilejowanej pozycji pod względem dostępu do środków polityki regionalnej, a w przypadku regionu czeskiego respondenci podkreślali, że środki zewnętrzne wciąż nie przystają do skali potrzebnych działań restrukturyzacyjnych. Dość istotnym elementem interwencji zewnętrznej było funkcjonowanie instytucji publicznych finansowanych ze szczebla centralnego (za wyjątkiem regionu węgierskiego, który jednak korzysta pod tym względem z bliskości Budapesztu). Szczególne znaczenie przypisywano funkcjonowaniu publicznych uniwersytetów, które nie tylko tworzyły miejsca pracy i zasilały lokalne rynki pracy wykwalifikowanymi specjalistami, lecz także przyciągały studentów spoza regionu, co powodowało określone efekty mnożnikowe (konieczność zamieszkania i utrzymania). 
Wykorzystanie środków zewnętrznych na poziomie lokalnym i regionalnym było jednak w większym stopniu ukierunkowane na podniesienie jakości życia mieszkańców niż na projekty o prorozwojowym charakterze. Wynikało to z wieloletnich zaniedbań infrastrukturalnych i konieczności dostosowania się do unijnych norm i standardów pod względem ochrony środowiska oraz ochrony zdrowia. Wśród projektów o charakterze prorozwojowym stosunkowo niewiele dotyczyło wprost sektora MSP, wspierania potencjału innowacyjnego oraz budowy społeczeństwa informacyjnego, a więcej - tworzenia ogólnych warunków rozwoju infrastruktury technicznej, w tym transportowej. Na tym tle pozytywnie wyróżniały się inicjatywy służące podniesieniu jakości szkolnictwa, zwłaszcza na poziomie średnim, oraz inicjatywy związane ze zwiększaniem potencjału innowacyjnego (inicjatywy klastrowe, parki technologiczne itd.).

W rezultacie interwencja zewnętrzna była sprzyjającym, ale nie zawsze koniecznym warunkiem osiągnięcia sukcesu. Przykładem był węgierski region Komárom-Esztergom, w którym - co podkreślano - sukces był w dużej mierze zasługą władz lokalnych, które - nie mogąc liczyć na pomoc rządową - jeszcze w latach dziewięćdziesiątych musiały podjąć trud samodzielnego rozwiązywania problemów restrukturyzacji przemysłu. Brak pomocy zewnętrznej wskazywano wręcz jako czynnik, który zmobilizował lokalne elity do prowadzenia aktywnej polityki rozwojowej. Jak twierdzono, sukces udało się osiągnąć w warunkach dyskryminacji ze strony rządowej agencji odpowiedzialnej za inwestycje zagraniczne, kierującej kapitał raczej do wschodniej i południowej części kraju.

\section{WNIOSKI}

Jednym z głównych wniosków płynących z powyższych badań jest relatywnie niewielka skala sukcesu mierzonego dynamiką PKB w pozametropolitalnych regionach przemysłowych w okresie przedkryzysowym. Tylko niektóre z nich utrzymywały lub w niewielkim stopniu poprawiały swoją pozycję w odniesieniu do średniej krajowej. Z reguły było to efektem obarczenia ich dziedzictwem przemysłowym, na które często składały się branże o charakterze tradycyjnym, oraz brak znaczących inwestycji w przemysłach wysokiej techniki. Rozwój ograniczany był też przez konieczność ponoszenia znacznych kosztów związanych z zagospodarowywaniem ugorów przemysłowych po upadłych przedsiębiorstwach. Ponadto, regionalne rynki pracy były stosunkowo mało elastyczne i wymagały znacznych nakładów na przekwalifikowanie pracowników, co skutkowało stosunkowo wysokimi stopami bezrobocia.

W rozwoju tej grupy regionów kluczową rolę odegrały czynniki zewnętrzne, przede wszystkim w postaci napływu znaczących inwestycji zagranicznych. Z drugiej strony, powiązania kooperacyjne dużych firm zagranicznych z lokalnym firmami były z reguły niewielkie, gdyż międzynarodowe koncerny często budują własną sieć dostawców w wymiarze wykraczającym poza dany podregion. Innym istotnym rodzajem interwencji zewnętrznej były finansowane centralnie instytucje publiczne, w tym zwłaszcza uczelnie wyższe, które z jednej strony tworzyły miejsca pracy, a z drugiej przyciągały studentów z innych regionów lub ograniczały odpływ miejscowych studentów do metropolitalnych ośrodków akademickich. Ważną rolę odegrały również transfery z budżetu centralnego, służące rozwiązaniu różnorodnych problemów społecznych związanych z procesami restrukturyzacji. 
Rola czynników endogenicznych w procesach rozwoju była stosunkowo niewielka. Wynikało to z relatywnie niedużego potencjału badawczo-rozwojowego, zwłaszcza w porównaniu z regionami metropolitalnymi. Dotyczyło to zarówno sektora publicznego, jak i prywatnego. Natomiast skala rozwoju lokalnej przedsiębiorczości była dość zróżnicowana. Przeważały mikroprzedsiębiorstwa zajmujące się tradycyjnym rodzajami działalności, zwłaszcza w zakresie usług rynkowych. Liczba aktywnych i odnoszących sukcesów średnich przedsiębiorstw była przy tym stosunkowo niewielka.

W zakresie polityk publicznych można zauważyć duże znaczenie dla sukcesu realizowanych działań strategicznych dobrze rozwiniętej współpracy między różnymi grupami aktorów. Jednak widoczne było także dość tradycyjne podejście do interwencji zewnętrznej, z naciskiem na rozwój infrastruktury technicznej, w tym transportowej oraz społecznej, a nie na gospodarczą orientację tych polityk. Przekładało się to też na wyrażane opinie o większym znaczeniu dużych inwestycji centralnych realizowanych w ramach polityk sektorowych dla rozwoju regionu niż polityki stricte regionalnej.

Należy oczekiwać, że wraz z upływem lat model rozwoju oparty na atrakcyjności dla napływu kapitału zagranicznego będzie ulegać stopniowemu wyczerpaniu, a kluczowego znaczenia zaczną nabierać zakorzenione lokalnie zasoby umożliwiające konkurowanie pod względem innowacyjności oferowanych produktów i rozwiązań (Stimson, Stough, Nijkamp, 2011; Gust-Bardon, 2014). Należy jednocześnie zauważyć, że nawet metropolie krajów Europy Środkowo-Wschodniej wciąż są relatywnie dalekie od tego modelu rozwoju (Smętkowski, 2018). Oznacza to wzmożoną konieczność zaangażowania władz lokalnych w uruchamianie nowych zasobów rozwojowych, opartych na jakości kapitału ludzkiego czy przedsiębiorczości ukierunkowanej na wykorzystywanie szans rynkowych. Takie przejawy były widoczne w części regionów, które osiągnęły relatywny sukces w okresie przedkryzysowym. Powinno to zastąpić model wykorzystania prostych zasobów rozwoju głównie dzięki rozwojowi infrastruktury technicznej, co było głównym kierunkiem działań w pierwszym okresie członkowstwa państw regionu w Unii Europejskiej (Ciffolilli, Condello, Pompili, Roemish, 2015). Kryzys gospodarczy z 2008 roku obnażył słabość dotychczasowego modelu rozwoju regionów krajów Europy Środkowo-Wschodniej, ale jak dotąd nie doprowadził do wyraźnych zmian pod tym względem, zwłaszcza w odniesieniu do regionów pozametropolitalnych.

\section{Literatura \\ References}

Blažek, J., Bečicová, I. (2014). Moravian-Silesian Region (Subregion Nuts 3) as an Example of a Successful Transformation - Case Study Report. GRINCOH Working Paper Series, Paper No. 6.03.01.03.

Braudel, F. (1970). History and the social sciences: The long term. Social Science Information, 9(1), 144-174.

Ciffolilli, A., Condello, S., Pompili, M., Roemish, R. (2015). Geography of Expenditure. Final Report. Work Package 13. Ex post evaluation of Cohesion Policy programmes 2007-2013, focusing on the European Regional Development Fund (ERDF) and the Cohesion Fund (CF). European Commission.

Constantin, D., Goschin, Z. (2014). The Alba County (Subregion Nuts 3) as an Example of a Successful Transformation - Case Study Report. GRINCOH Working Paper Series, Paper No. 6.03.01.01.

Domański, B. (2003). Industrial change and foreign direct investment in the postsocialist economy: the case of Poland. European and Regional Studies, 10(2), 99-118. 
Domański, B. (2015). Współczesne procesy przemian regionalnych przemysłu Polski - próba interpretacji. Prace Komisji Geografii Przemysłu Polskiego Towarzystwa Geograficznego, 29(4), 40-53.

Eurostat (2017, 1 grudnia). Pozyskano z http://ec.europa.eu/eurostat/

Gierańczyk, W. (2008). Problematyka definiowania zmian w tendencjach lokalizacyjnych przedsiębiorstw przemysłowych w dobie globalizacji. Prace Komisji Geografii Przemysłu Polskiego Towarzystwa Geograficznego, 11, 86-97.

Gierańczyk, W. (2014). Economic situation in the manufacturing sector as an example of modern research in industrial geography in Poland. Prace Komisji Geografii Przemysłu Polskiego Towarzystwa Geograficznego, 25, 38-55.

Gierańczyk, W., Rachwał, T. (2012). Structural Changes in the Industry of Poland Aagainst the Background of Eastern European Union States. Quaestiones Geographicae, 31(2), 83-93.

Gilowska, Z., Gorzelak, G., Jałowiecki, B., Sobczak, K. (1998). Kierunki polityki regionalnej Polski. Studia Regionalne i Lokalne, 57.

Gorzelak, G. (1995). Transformacja systemowa a restrukturyzacja regionalna. Warszawa: EUROREG, Uniwersytet Warszawski.

Gorzelak, G. (2003). Bieda i zamożność regionów. Założenia, hipotezy, przykłady. Studia Regionalne i Lokalne, 1(11), 37-59.

Gust-Bardon, N.I. (2014). Regional development in the context of an innovation process. International Journal of Innovation and Regional Development, 5(4-5), 349-366.

Haugh, D., Mourougane, A., Chatal, O. (2010). The automobile industry in and beyond the crisis. OECD Economics Department Working Papers, No. 745. Paris: OECD Publishing.

Jaklič, A., Svetličič, M. (2003). Enhanced Transition Through Outward Internationalization: Outward FDI by Slovenian Firms. Hampshire: Ashgate.

Kostrubiec, B. (2006). Delokalizacja przedsiębiorstw - przejaw światowej samoregulacji. Prace Komisji Geografii Przemysłu Polskiego Towarzystwa Geograficznego, 8, 37-46.

Kukliński, A., Jałowiecki, B. (red.) (1991). Restrukturyzacja regionów jako problem współpracy europejskiej. Studia Regionalne i Lokalne, 34.

McMillan, M.S., Rodrik, D. (2011). Globalization, structural change and productivity growth. NBER Working Paper No. 17143. Cambridge, MA: National Bureau of Economic Research.

Mikołajewicz, Z. (1995). Procesy restrukturyzacji przemysłu w regionach. Opole: Uniwersytet Opolski.

Olsen, K.B. (2006). Productivity impacts of offshoring and outsourcing. A review. STI Working Paper 1, OECD.

Poniatowska-Jaksch, M. (2006). Przemysłowe bezpośrednie inwestycje zagraniczne źródłem konkurencyjności regionu. Warszawa: Szkoła Główna Handlowa.

Rachwał, T. (2010). Struktura przestrzenna i działowa przemysłu Polski na tle Unii Europejskiej w dwudziestolecie rozpoczęcia procesów transformacji systemowej, Prace Komisji Geografii Przemysłu Polskiego Towarzystwa Geograficznego, 16, 105-124.

Rachwał, T. (2011a). Industrial restructuring in Poland and other European Union states in the era of economic globalization. Procedia-Social and Behavioral Sciences, 19, 1-10.

Rachwał, T. (2011b). Transformations of the Employment Structure as an Expression of the Transformation of Polish Industry against the Background of the European Union. Bulletin of Geography. Socio-economic series, 15(15), 5-25.

Rachwał, T. (2011c). Wpływ kryzysu na zmiany produkcji przemysłowej w Polsce. Prace Komisji Geografii Przemysłu Polskiego Towarzystwa Geograficznego, 17, 99-113.

Rachwał, T. (2015). Structural changes in Polish industry after 1989. Geographia Polonica, 88(4), $575-605$.

Rachwał, T., Wiedermann, K., Kilar, W. (2009). Rola przemysłu w gospodarce układów regionalnych Unii Europejskiej. Prace Komisji Geografii Przemysłu Polskiego Towarzystwa Geograficznego, 14, 31-42.

Radło, M.J., Spałek, P. (2017). Deklarowana i rzeczywista polityka przemysłowa Polski w świetle danych o pomocy publicznej w latach 2007-2014. Prace Komisji Geografii Przemysłu Polskiego Towarzystwa Geograficznego, 31(1), 7-23.

Radosevic, S., Rozeik, A. (2005). Foreign Direct Investment and Restructuring in the Automotive Industry in Central and East Europe. Economics Working Papers, 53. 
Scott, J., Szalai, B. (2014). The Komárom-Esztergom County (Subregion Nuts 3) as an Example of a Successful Transformation - Case Study Report. GRINCOH Working Paper Series, Paper No. 6.03.01.02.

Smętkowski, M. (2008). Rola specjalnych stref ekonomicznych w kształtowaniu struktury przestrzennej przemysłu w Polsce. Prace Komisji Geografii Przemysłu Polskiego Towarzystwa Geograficznego, 10, 204-216.

Smętkowski, M. (2013). Rozwój regionów i polityka regionalna w krajach Europy ŚrodkowoWschodniej w okresie transformacji i globalizacji. Warszawa: Wydawnictwo Naukowe Scholar.

Smętkowski, M., (2018) The role of exogenous and endogenous factors in the growth of regions in Central and Eastern Europe: the metropolitan/non-metropolitan divide in the pre- and post-crisis era. European Planning Studies, 26(2), 256-278.

Smętkowski, M., Gorzelak, G., Kozak, M., Olechnicka, A., Płoszaj, A., Wojnar, K. (2011). The European Metropolises and their regions: from Economic Landscape to Metropolitan Networks. Warszawa: Wydawnictwo Naukowe Scholar.

Stimson, R.J., Stough, R., Nijkamp, P. (red.) (2011). Endogenous regional development: perspectives, measurement and empirical investigation. Edward Elgar Publishing.

Stryjakiewicz, T. (1999). Adaptacja przestrzenna przemysłu w Polsce w warunkach transformacji. Poznań: Wydawnictwo Naukowe Uniwersytetu im. Adama Mickiewicza.

Tkocz, M. (2001). Restrukturyzacja przemysłu regionu tradycyjnego. Katowice: Wydawnictwo Uniwersytetu Śląskiego.

Ulbrych, M. (2014). Znaczenie przemysłu w gospodarce i polityce regionalnej Unii Europejskiej. Prace Komisji Geografii Przemysłu Polskiego Towarzystwa Geograficznego, 26, 31-45.

Wieloński, A., Bazydło, A. (2002). Proces integracji z Unią Europejską a przemiany strukturalne w przemyśle Polski. Prace Komisji Geografii Przemysłu Polskiego Towarzystwa Geograficznego, 41, 19-24.

Wishlade, F. (2003). Regional State Aid and Competition Policy in the EU. Alphen, Londyn: Kluwer. Zioło, Z. (2008). Procesy transformacji przemysłowych układów przestrzennych na tle zmieniającego się otoczenia. Prace Komisji Geografii Przemysłu Polskiego Towarzystwa Geograficznego, $10,11-22$.

Zioło, Z. (2010). Uwarunkowania kształtowania się procesów transformacji przemysłu i usług. Prace Komisji Geografii Przemysłu Polskiego Towarzystwa Geograficznego, 15, 45-60.

Zioło, Z. (2017). Wpływ przemysłu i usług na rozwój społeczno-gospodarczy układów przestrzennych. Prace Komisji Geografii Przemysłu Polskiego Towarzystwa Geograficznego, 31(4), 7-24.

Maciej Smętkowski, dr hab., geograf społeczno-ekonomiczny, adiunkt w Centrum Europejskich Studiów Regionalnych i Lokalnych (EUROREG) Uniwersytetu Warszawskiego. Autor wielu publikacji poświęconych procesom metropolizacji, instrumentom polityki regionalnej oraz współpracy transgranicznej, w tym m.in. książek Rozwój regionów i polityka regionalna w krajach Europy Środkowo-Wschodniej w okresie transformacji i globalizacji i Europejskie metropolie i ich regiony. Od krajobrazu gospodarczego do sieci metropolii. Posiada duże doświadczenie w ewaluacji polityk publicznych. Uczestnik licznych międzynarodowych i krajowych projektów badawczych realizowanych m.in. w ramach programów badań UE (w tym Horizon 2020) oraz programu ESPON (Europejskiej Sieci Obserwatoriów Planowania Przestrzennego). Przewodniczący Zarządu Stowarzyszenia Regional Studies Association - Sekcja Polska.

Maciej Smętkowski, Ph.D. in earth sciences, specialty socio-economic geography, assistant profesor at the Centre for European Regional and Local Studies (EUROREG), University of Warsaw. Author of publications on the metropolisation process, instruments of regional policy and cross-border co-operation, including books "Regional Development and Regional Policy in Central and Eastern European Countries in the Period of Transformation and Globalisation" and "The European Metropolises and Their Regions: from Economic Landscape to Metropolitan Networks". He has extensive experience in evaluation of public policies. He has been involved in a number of research projects carried-out within research framework programmes of the EU (including Horizon 2020) and ESPON Programme (European Spatial Planning Observatory Network). Chair of the Polish Section of the Regional Studies Association. 


\title{
Adres/address:
}

Uniwersytet Warszawski

Centrum Europejskich Studiów Regionalnych i Lokalnych (EUROREG)

ul. Krakowskie Przedmieście 30, 00-927 Warszawa, Polska

e-mail: m.smetkowski@uw.edu.pl

Dorota Celińska-Janowicz, dr nauk o Ziemi w zakresie geografii, absolwentka geografii i gospodarki przestrzennej na Uniwersytecie Warszawskim. Laureatka dyplomu im. Eugeniusza Romera przyznawanego przez Komitet Nauk Geograficznych Polskiej Akademii Nauk, a także stypendiów podoktorskich na Uniwersytecie w Wiedniu oraz na Wolnym Uniwersytecie w Berlinie. W EUROREG-u pracuje od 2010 roku, kiedy to objęła także stanowisko sekretarza redakcji kwartalnika naukowego „Studia Regionalne i Lokalne”. Uczestniczyła w kilku projektach programu ESPON oraz w badaniach ewaluacyjnych i dotyczących rozwoju regionalnego i lokalnego, realizowanych na zlecenie Ministerstwa Rozwoju Regionalnego, NCBiR oraz Urzędu Miasta st. Warszawy. Od września 2016 roku pełni funkcję kierowniczki ds. toku studiów. Jej zainteresowania badawcze koncentrują się wokół zagadnień związanych z geografią handlu, studiami miejskimi, planowaniem przestrzennym oraz rozwojem regionalnym i lokalnym.

Dorota Celińska-Janowicz, Ph.D. in earth sciences, specialty geography. She graduated geography and spatial economy at the University of Warsaw. She was awarded post-doc sholarships at the University of Vienna and the Free University of Berlin as well as the Eugeniusz Romer Prize of the Committee on Geographical Sciences of the Polish Academy of Sciences for the best Ph.D. theses in socio-economic geography. She has been working at Euroreg since 2010, when she also became an Executive Editor of scientific quarterly "Regional and Local Studies". She has participated in several ESPON projects as well as evaluation studies and projects on regional and local development commissioned by the Ministry of Regional Development and the Warsaw City Hall. Since September 2016 she has been a Counselor for Students' Affairs. Her research interests focus on retail geography, urban studies, spatial planning as well as regional and local development.

\section{Adres/address:}

\author{
Uniwersytet Warszawski \\ Centrum Europejskich Studiów Regionalnych i Lokalnych (EUROREG) \\ ul. Krakowskie Przedmieście 30, 00-927 Warszawa, Polska \\ e-mail: d.celinska@uw.edu.pl
}

Artykuł przedstawia wyniki badań zrealizowanych w ramach projektu GRINCOH (Growth - Innovation Competitiveness: Fostering Cohesion in Central and Eastern Europe), finansowanego ze środków VII Ramowego Programu Badań Unii Europejskiej. 